\title{
Procedures for calculation of the albedo with OLI-Landsat 8 images: Application to the Brazilian semi-arid
}

\author{
Bernardo B. da Silva ${ }^{1,2}$, Alexandra C. Braga ${ }^{2}$, Célia C. Braga ${ }^{2}$, \\ Leidjane M. M. de Oliveira ${ }^{3}$, Suzana M. G. L. Montenegro ${ }^{4} \&$ Bernardo Barbosa Junior $^{5}$ \\ ${ }^{1}$ Fundação de Amparo à Ciência e Tecnologia de Pernambuco. Recife. PE E-mail: bbdasilva.ufpe@gmail.com (Corresponding author) \\ ${ }^{2}$ Universidade Federal de Campina Grande/Programa de Pós-Graduação em Meteorologia. Campina Grande, PB. E-mail: alexandrachavesb@gmail.com; \\ celia@dca.ufcg.edu.br \\ ${ }^{3}$ Universidade Federal de Pernambuco. Caruaru, PE. E-mail: leidjaneoliveira@hotmail.com \\ ${ }^{4}$ Universidade Federal de Pernambuco/Departamento de Engenharia Civil. Recife, PE. E-mail: suzanam.ufpe@gmail.com \\ ${ }^{5}$ Universidade Federal da Paraíba. João Pessoa, PB. E-mail: bernardobarbosaj@yahoo.com
}

\section{Key words:}

radiance

spectral reflectance

atmospheric transmittance

net radiation

\begin{abstract}
A B S T R A C T
The surface albedo plays an important role in the exchanges of energy and mass in the planetary boundary layer. Therefore, changes in albedo affect the balance of radiation and energy at the surface, which can be detected with its monitoring. Albedo determination has been performed through various sensors, but there is not yet any publication dealing with albedo calculation procedures using OLI (Operational Land Imager) - Landsat 8 images. The objective of the study is to present the procedures for computing the albedo with OLI images and map it in irrigated areas of the São Gonçalo Irrigated District, PB, Brazil. Images of the year 2013, path 215 and row 65, were selected. The data necessary for calculating the albedo were extracted from each image metadata: additive and multiplicative terms of radiance and reflectance, and sun elevation angle. There were large differences between the albedo values of irrigated plots, water bodies and native vegetation. The albedo obtained with OLI images provides a higher degree of differentiation of the various types of land use, due to the substantial increase in the radiometric resolution of this new sensor.
\end{abstract}

\section{Palavras-chave:}

radiância

reflectância espectral

transmitância atmosférica

saldo de radiação

\section{Procedimentos para cômputo do albedo com imagens OLI-Landsat 8: Aplicação ao semiárido brasileiro}

\section{R E S U M O}

O albedo da superfície desempenha papel importante nas trocas de energia e massa na camada limite planetária. Neste sentido, alterações no albedo modificam os balanços de radiação e energia à superfície, que podem ser detectadas com seu monitoramento. A determinação do albedo tem sido feita através de diversos sensores mas ainda não foram publicados procedimentos de cálculo do mesmo com imagens do OLI (Operational Land Images) do Landsat 8 . O objetivo do estudo é apresentar, em detalhes, procedimentos de cômputo do albedo com imagens OLI e mapear o mesmo em áreas do perímetro irrigado São Gonçalo, PB. Foram selecionadas imagens do ano 2013, órbita e ponto 215 e 65, respectivamente. Os dados necessários ao cômputo do albedo foram extraídos do meta dados de cada imagem, quais sejam: termos aditivo e multiplicativo da radiância e reflectância das bandas de 2 a 7 e ângulo de elevação do Sol. Verificaram-se grandes diferenças entre os valores do albedo das parcelas irrigadas, corpos d'água e de vegetação nativa. Concluise que o albedo obtido com as imagens OLI apresenta maior grau de diferenciação dos diversos tipos de uso da terra, resultado do aumento substancial da resolução radiométrica deste novo sensor. 


\section{INTRODUCTION}

Net radiation plays a fundamental role in biophysical processes involving exchanges of energy and mass in the planetary boundary layer, since it constitutes the main energy source used in the heating of soil and air, and in plant evapotranspiration (Silva et al., 2005a; Wang \& Davison, 2007; Giongo et al., 2010; Lopes et al., 2013; Souza et al., 2014). Surface albedo substantially affects net radiation; thus, many satellites carry sensors (TM - Landsat 5, ETM+ - Landsat 7, AVHRR-NOAA, MODIS - Terra/Aqua, ASTER - Terra, among others) that determine and monitor the Earth's surface albedo. Therefore, its monitoring has increasingly gained importance, since the alterations caused by natural and/or anthropic phenomena on the surface of the planet can be detected by orbital sensors, besides the role played by the albedo in climatic modeling.

There are different algorithms for the calculation of surface albedo that use radiometric measurements of AVHRR bands 1 and 2, some of which relate the spectral planetary reflectances of these bands to the surface albedo (Wydick et al., 1987; Hucek \& Jacobowitz, 1995). More recently, Liang (2000) obtained, for various orbital sensors, equations that allow calculating the albedo through the linear combination of the monochromatic reflectivity of each one of these bands in the solar radiation domain. Souza et al. (2014) applied the parametrization proposed by Tasumi et al. (2008) with high and low loadings of aerosols in different regions of Brazil and data of the MODIS sensor. However, the model proposed by Zhong \& Li (1988) employed by Bastiaanssen et al. (1998) in the SEBAL (Surface Energy Balance Algorithm for Land) and initially applied to TM - Landsat 5 images, combines simplicity and precision. This model has been widely used in many studies on the balance of radiation (Silva et al., 2005b; 2011; Lopes et al., 2013; Gusmão et al., 2012), energy (Silva \& Bezerra, 2006; Allen et al., 2007; Arraes et al., 2012; Bezerra et al., 2014; Machado et al., 2014; Mattar et al., 2014) and in researches analyzing alterations in land use and occupation (Rodrigues et al., 2009; Giongo et al., 2010; Oliveira et al., 2012).

The albedo has also been used in climatic modeling and Krayenhoff \& Voogt (2010) studied its influence on air temperature, while Wang \& Davison (2007) evaluated the impact of climatic variations on the albedo of temperate regions in Canada. Loew \& Govaerts (2010), evaluated the consistency of long-term albedo data obtained with the Meteosat First Generation, used in climatic modeling. In addition, it should be pointed out the role of cloud albedo in climatic monitoring and analysis studied by Mueller et al. (2011).

In most studies using TM and ETM+, particularly in applications of radiation and energy balance, the albedo is initially obtained through combinations of reflective bands without atmospheric correction and then the atmospheric effects are corrected based on the formulation proposed by Zhong \& Li (1988), intensively used by Bastiaanssen et al. (1998). More recently, Tasumi et al. (2008) developed an algorithm for the atmospheric correction of each one of the TM and MODIS reflective bands, but based on the same correction model proposed by Zhong \& $\mathrm{Li}$ (1988). The main difference is that in the latter the correction is performed in the planetary albedo, while in the former the atmospheric correction is performed band to band, obtained through a radiative transfer model. This is the method adopted by the METRIC (Mapping Evapotranspiration with Internalized Calibration), a variation of the SEBAL and also used in mountainous areas (Allen et al., 2007; Tasumi et al., 2008).

Although albedo has been used in many researches involving radiation and energy balances based on TM or ETM+ images, there are no published studies that allow its determination using images from OLI (Operational Land Imager), aboard Landsat 8, launched on February 11, 2013 by NASA (National Aeronautics and Space Administration). Therefore, this study aimed to present the procedures that allow albedo determination with OLI-Landsat 8 images and use them in the mapping of areas under irrigation and native vegetation in the São Gonçalo Irrigation District-PB, Brazil.

\section{Material ANd Methods}

The studied area comprehends part of the Piranhas-Açu river basin, in the semiarid region of Northeastern Brazil, and is located in the states of Paraíba and Rio Grande do Norte. The area comprises seven sub-basins: Piancó, Peixe, Alto Piranhas, Médio-Piranhas, Espinharas, Seridó and Baixo Piranhas. In the Alto Piranhas sub-basin, there is the main irrigation district of the Paraíba state, called São Gonçalo Irrigation District - SGID, which is located $15 \mathrm{~km}$ distant from the municipality of Sousa$\mathrm{PB}\left(6.84^{\circ} \mathrm{S} ; 38.32^{\circ} \mathrm{W} ; 234 \mathrm{~m}\right)$, approximately $440 \mathrm{~km}$ from the state capital, João Pessoa. The studied area encompasses, besides the São Gonçalo Irrigation District (SGID I and II), the São Gonçalo dam, areas of native vegetation, rainfed agriculture and areas with large soil exposure (Figure 1).

The climate of the studied region is classified as semiarid, DdA', according to the methodology of Thornthwaite \& Matther (1944), with rainy season concentrated from January to May (Table 1). The annual means of air temperature, rainfall and potential evapotranspiration - ETp are respectively equal to $26.6^{\circ} \mathrm{C}, 904.1 \mathrm{~mm}$ and $1418 \mathrm{~mm}$, but minimum and maximum temperatures range from 19.4 to $22.3^{\circ} \mathrm{C}$, and 31.5 to $35.6{ }^{\circ} \mathrm{C}$,

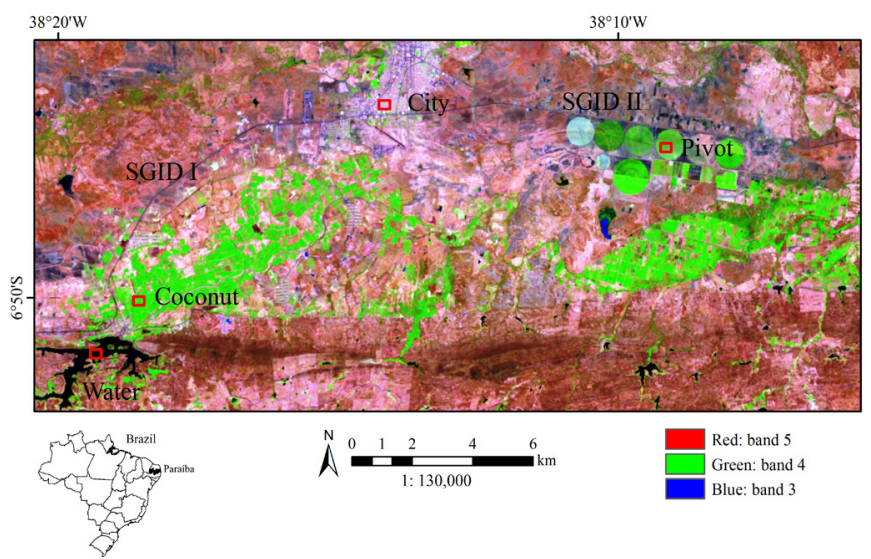

Figure 1. Section of OLI-Landsat 8 image on September 12, 2013, in RGB453 composition and highlights for the areas of Sçao Gonçalo Irrigation District (SGID) I and II and other areas selected for analysis of the results 
Table 1. Mean rainfall - MR (mm), standard deviation - SD $(\mathrm{mm})$ and monthly mean air temperature - Ta $\left({ }^{\circ} \mathrm{C}\right)$, according to the records of the Academic Unit of Atmospheric Sciences of the Federal University of Campina Grande (UFCG)

\begin{tabular}{ccccccccccccc}
\hline \multirow{2}{*}{ Variable } & \multicolumn{1}{c}{ Jan } & Feb & Mar & Apr & May & Jun & Jul & Aug & Sep & Oct & Nov & Dec \\
\cline { 2 - 13 } MR & 96.0 & 176.1 & 247.2 & 175.7 & 68.8 & 34.6 & 15.8 & 5.6 & 4.6 & 11.7 & 18.6 & 41.2 \\
SD & 69.4 & 106.3 & 107.9 & 112.7 & 62.4 & 44.4 & 20.0 & 9.5 & 12.4 & 17.9 & 32.1 & 47.9 \\
Ta & 27.5 & 26.5 & 26.2 & 26.0 & 25.8 & 25.3 & 25.3 & 26.3 & 27.2 & 27.8 & 27.8 & 27.9 \\
\hline
\end{tabular}

respectively. The prevailing soils in the area are Latosols and Cambisols and the natural vegetation is classified as contact between Caatinga and Seasonal Forest and Pioneer Formations with Fluviomarine Influence.

Five OLI-Landsat 8 images, path 216 and row 65, generated in 2013 and obtained from the United States Geological Survey - USGS (http://earthexplorer.usgs.gov/) were used in the study. These images correspond to the Landsat 8 overpass approximately at $09 \mathrm{~h} 45 \mathrm{~min}$ (local time), and have spatial resolution of $30 \mathrm{~m}$ and spectral resolution of 12 bits, but are available in 16 bits, which means an intensity in each pixel between 0 and 65,535 gray levels, ensuring a higher detailing degree of the generated information. In addition, meteorological data recorded close to the Landsat 8 pass over the studied area were used, in order to determine the atmospheric transmittance used in the atmospheric correction. The selected days and the data used in the image processing are shown in Table 2.

The albedo was calculated using the following equation (Zhong \& Li, 1988; Bastiaanssen et al., 1998):

$$
\alpha=\frac{\left(\alpha_{\mathrm{toa}}-\alpha_{\mathrm{atm}}\right)}{\tau_{\mathrm{oc}}^{2}}
$$

where:

$\alpha_{\text {toa }}$ - planetary albedo of each pixel or albedo without atmospheric correction;

$a_{\text {atm }}$ - atmospheric albedo; and

$\tau_{\text {oc }}$ - atmospheric transmittance in the solar radiation domain, which can be obtained by the equation (Allen et al., 2002, 2007):

$$
\tau_{\mathrm{oc}}=0.35+0.627 \exp \left[-\frac{0.00146 \mathrm{Po}}{\mathrm{K}_{\mathrm{t}} \cos \mathrm{Z}}-0.075\left(\frac{\mathrm{W}}{\cos \mathrm{Z}}\right)^{0.4}\right]
$$

where:

Po - local atmospheric pressure $(\mathrm{kPa})$;

$\mathrm{K}_{\mathrm{t}} \quad$ - air turbidity coefficient $\left(\mathrm{K}_{\mathrm{t}}=1.0\right.$ for clear air and $\mathrm{K}_{\mathrm{t}}$ $=0.5$ for extremely turbid or polluted air; $K_{t}=1.0$ was used in this study);

$\mathrm{Z}$ - Sun zenith angle (extracted from the image metadata);
$\mathrm{W}(\mathrm{mm})$ - precipitable water, obtained as a function of RU (\%); and

Po - according to the equation of Allen et al. (2002).

$$
\mathrm{W}=0.14 \mathrm{e}_{\mathrm{a}} \mathrm{P}_{\mathrm{o}}+2.1
$$

where:

$\mathrm{e}_{\mathrm{a}} \quad$ - partial pressure of atmospheric water vapor $(\mathrm{KPa})$.

The value of atmospheric albedo can be obtained through a radiative transfer model and, in general, is situated between 0.025 and 0.040 (Allen et al., 2002). The value of 0.03 was adopted in the present study. The determination of albedo without atmospheric correction $\left(\alpha_{\text {toa }}\right)$ was performed through linear combination of the monochromatic reflectance $\left(\mathrm{r}_{\mathrm{b}}\right)$ of the reflective bands (from 2 to 7 ) of the OLI - Landsat 8 (Eq. $5)$, according to the following equation:

$$
\alpha_{\text {toa }}=\mathrm{p}_{2} \times \mathrm{r}_{2}+\mathrm{p}_{3} \times \mathrm{r}_{3}+\mathrm{p}_{4} \times \mathrm{r}_{4}+\mathrm{p}_{5} \times \mathrm{r}_{5}+\mathrm{p}_{6} \times \mathrm{r}_{6}+\mathrm{p}_{7} \times \mathrm{r}_{7}
$$

where the reflectance of each one of the bands (from 2 to 7 ) was obtained by Chander \& Markham (2003):

$$
\mathrm{r}_{\mathrm{b}}=\frac{\left(\operatorname{Add}_{\mathrm{ref}, \mathrm{b}}+\mathrm{Mult}_{\mathrm{ref}, \mathrm{b}} \mathrm{ND}_{\mathrm{b}}\right)}{\cos \mathrm{Zd}_{\mathrm{r}}}
$$

where:

Add $_{\text {ref,b }}$ and Mult ${ }_{\text {ref, }}$ - represent additive and multiplicative terms of the reflectance of each band, extracted from the metadata of each image (group = radiometric_rescaling), as well as the Sun zenith angle - Z;

$\mathrm{ND}_{\mathrm{b}}$ - intensity of each pixel and band (value between 0 and 65365);

b - subscript representing each one of the six OLI bands; and

$d_{r} \quad$ - corresponds to the correction of the eccentricity of the terrestrial orbit, given by:

$$
\mathrm{d}_{\mathrm{r}}=\left(\frac{1}{\mathrm{~d}_{\mathrm{ES}}}\right)^{2}
$$

\begin{tabular}{|c|c|c|c|c|c|c|c|c|}
\hline Date & OD & $\bar{E}$ & $\operatorname{Cos} Z$ & $\mathrm{Ta}$ & $\overline{R U}$ & $\mathrm{Po}_{0}$ & $\tau_{0 c}$ & $\overline{d_{E S}}$ \\
\hline 24/06/13 & 175 & 48.9197 & 0.754 & 26.0 & 45.5 & 98.9 & 0.735 & 1.016394 \\
\hline $12 / 09 / 13$ & 255 & 61.2803 & 0.877 & 28.6 & 46.0 & 98.8 & 0.736 & 1.013438 \\
\hline $28 / 09 / 13$ & 271 & 64.4913 & 0.903 & 28.4 & 32.5 & 98.7 & 0.761 & 1.006343 \\
\hline $14 / 10 / 13$ & 287 & 66.2192 & 0.915 & 30.4 & 36.5 & 98.8 & 0.756 & 0.997334 \\
\hline $15 / 11 / 13$ & 319 & 64.2910 & 0.901 & 29.1 & 46.0 & 98.7 & 0.749 & 0.992973 \\
\hline
\end{tabular}

where:

Table 2. Variables used in albedo calculation for the studied area: Sun elevation angle - E (degree), cosine of the Sun zenith angle - $\cos \mathrm{Z}$, air temperature - Ta $\left({ }^{\circ} \mathrm{C}\right)$, relative air humidity - RU $(\%)$, atmospheric pressure - Po $(\mathrm{kPa})$ and atmospheric transmittance $-\tau_{\mathrm{oc}}$, referring to the moment of the satellite overpass on the days selected for the study, and Earth-to-Sun distance - $\mathrm{d}_{\mathrm{ES}}$ (astronomic unit) in each selected day 
$\mathrm{d}_{\mathrm{ES}}$ - Earth-to-Sun distance (astronomic unit) on the day of each image, also extracted from the metadata.

For the determination of each weight $\left(\mathrm{p}_{\mathrm{b}}\right)$, it is necessary to estimate the solar constant $\left(\mathrm{K}_{\mathrm{b}}, \mathrm{W} \mathrm{m}^{-2} \mu \mathrm{m}^{-1}\right)$ associated with each one of the OLI reflective bands and, for this, the Eq. 7 was used according to Chander \& Markham (2003).

$$
\mathrm{k}_{\mathrm{b}}=\frac{\pi \mathrm{L}_{\mathrm{b}}}{\mathrm{r}_{\mathrm{b}} \cos \mathrm{Zd}}
$$

where:

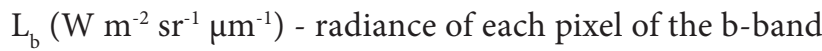
and the other terms have already been described.

For the determination of the $\mathrm{L}_{\mathrm{b}}$ of each pixel and band, the additive $\left(\operatorname{Add}_{\mathrm{rad}, \mathrm{b}}\right)$ and multiplicative (Mult $\left.\mathrm{rad}, \mathrm{b}\right)$ terms relative to the radiance were used, also extracted from the metadata of each image, calculated according to the equation:

$$
\mathrm{L}_{\mathrm{b}}=\mathrm{Add}_{\mathrm{rad}, \mathrm{b}}+\mathrm{Mult}_{\mathrm{rad}, \mathrm{b}} \mathrm{ND}_{\mathrm{b}}
$$

The value of each weight $\left(\mathrm{p}_{\mathrm{b}}\right)$ of each spectral band was obtained by the ratio between the $\mathrm{k}_{\mathrm{b}}$ of that band and the sum of all the $\mathrm{k}_{\mathrm{b}}$ values used in the calculation of the albedo, similar to what has been done in the SEBAL and METRIC (Bastiaanssen et al., 1998; Allen et al., 2007; Tasumi et al., 2008).

\section{Results AND Discussion}

The data extracted from the metadata, which were used in the calculation of the radiance and reflectance of OLI-Landsat 8 bands 2 to 7 , for two of the five days selected for the study are shown in Table 3. For each one of the selected days, the values of $\mathrm{Add}_{\mathrm{rad}}$ and Mult $\mathrm{rad}_{\mathrm{r}}$ were different. However, with respect to the reflectances, these factors remain constant, which constitutes an important simplification in the process of calculation of these reflectances. Many researches on radiation balance with Landsat 5 and 7 images have used maximum (Lmax) and minimum (Lmin) radiances in the process of conversion of the gray level into spectral radiance (Bastiaanssen et al., 1998; Allen et al., 2002; 2007; Silva et al., 2005b; 2011). These values were updated over time but remained constant for some years (Chander \& Markham, 2003; Chander et al., 2009). In the case of OLI-Landsat 8 , however, for each image obtained in 2013 used in this study, the values of Lmax and Lmin suffered changes. Therefore, it is recommended to determine radiation based on the additive and multiplicative terms (group = radiometric_rescaling), both in the calculation of spectral radiance and in the determination of spectral reflectance, for integrating the same group of metadata.

There are different techniques for the determination of surface albedo through orbital images. However, the most used one with Landsat images in researches involving radiation and energy balances results from the proposal developed by Zhong \& Li (1988). This technique requires the identification of the weights or relative contribution of each spectral band in the composition of the albedo in the entire solar radiation spectrum, which is widely known (Bastiaanssen el al., 1998; Allen et al., 2002; 2007; Silva et al., 2005a,b). For Landsat 8, these weights have not yet been published and one of the objectives of this study is their determination, specifically for OLI. For this, the specific solar constant $\left(\mathrm{K}_{\mathrm{b}}\right)$ of each one of the OLI bands from 2 to 7 was obtained based on Eq. 7. The values of $\mathrm{K}_{\mathrm{b}}\left(\mathrm{W} \mathrm{m} \mathrm{m}^{-2} \mu \mathrm{m}^{-1} \mathrm{sr}^{-1}\right)$ for the five selected days are shown in Table 4 . As observed for each OLI image, these values suffered a sharp change, resulting from the alterations of Lmax and Lmin, which were used for the radiometric calibration of TM and ETM+ images. Thus, based on these results, it is recommended not to use the methodology that employs Lmin and Lmax, but only the reflectances (Eq. 5) and the planetary albedo (Eq. 4) with the mean weights represented in Table 5. As can be seen in this Table, these values can be considered as

Table 4. Values of the solar constant $-\mathrm{K}_{\mathrm{b}}\left(\mathrm{W} \mathrm{m}^{-2} \mu \mathrm{m}^{-1} \mathrm{sr}^{-1}\right)$ specific for the OLI-Landsat 8 bands from 2 to 7 , in different

\begin{tabular}{|c|c|c|c|c|c|c|}
\hline \multirow{2}{*}{ Bands } & \multicolumn{5}{|c|}{$K_{b}\left(W m^{-2} \mu m^{-1} s r^{-1}\right)-0 D$} & \multirow{2}{*}{ Mean } \\
\hline & 175 & 255 & 271 & 287 & 319 & \\
\hline 2 & 1955.1 & 1994.3 & 2011.9 & 2030.4 & 2064.7 & 2011.3 \\
\hline 3 & 1801.6 & 1837.7 & 1853.8 & 1870.9 & 1902.6 & 1853.3 \\
\hline 4 & 1519.1 & 1549.6 & 1563.3 & 1577.6 & 1604.2 & 1562.8 \\
\hline 5 & 929.6 & 948.3 & 956.6 & 965.5 & 981.7 & 956.4 \\
\hline 6 & 231.2 & 235.8 & 237.9 & 240.1 & 244.1 & 237.8 \\
\hline 7 & 77.9 & 79.5 & 80.2 & 80.9 & 82.3 & 80.2 \\
\hline
\end{tabular}
ordinal dates (OD)

Table 5. Weights to be used in albedo calculation, specific for the OLI-Landsat 8 bands from 2 to 7 , in different ordinal dates (OD)

\begin{tabular}{ccccccc}
\hline \multirow{2}{*}{ Bands } & \multicolumn{7}{c}{ Albedo weights - 0D } & \multirow{2}{*}{ Mean } \\
\cline { 2 - 6 } & $\mathbf{1 7 5}$ & $\mathbf{2 5 5}$ & $\mathbf{2 7 1}$ & $\mathbf{2 8 7}$ & $\mathbf{3 1 9}$ & \\
2 & 0.300 & 0.301 & 0.300 & 0.300 & 0.301 & 0.300 \\
3 & 0.277 & 0.278 & 0.277 & 0.277 & 0.276 & 0.277 \\
4 & 0.233 & 0.233 & 0.233 & 0.233 & 0.233 & 0.233 \\
5 & 0.143 & 0.144 & 0.143 & 0.143 & 0.142 & 0.143 \\
6 & 0.035 & 0.036 & 0.035 & 0.035 & 0.035 & 0.036 \\
7 & 0.012 & 0.012 & 0.012 & 0.012 & 0.012 & 0.012 \\
\hline
\end{tabular}

Table 3. Values extracted from the metadata of the ordinal date - OD 175 (June 24) and 303 (October 30), with the respective multiplicative (Mult) and additive (Add) factors used in the calculation of radiance $\left(\right.$ Mult $_{\text {rad }}$ and $A_{d d}{ }_{\text {rad }}$ and

\begin{tabular}{|c|c|c|c|c|c|c|c|c|}
\hline \multirow{2}{*}{ Bands } & \multicolumn{4}{|c|}{$O D=175$} & \multicolumn{4}{|c|}{$O D=319$} \\
\hline & Mult $_{\text {rad }}$ & Add $_{\text {rad }}$ & Mult $_{\text {ref }}$ & $\mathbf{A d d}_{\mathrm{ref}}$ & Mult & Add $_{\mathrm{rad}}$ & Mult $t_{\text {ref }}$ & $\mathbf{A d d}_{\text {ref }}$ \\
\hline 2 & 0.012446 & -62.22917 & 0.00002 & -0.10000 & 0.013144 & -65.71817 & 0.00002 & -0.10000 \\
\hline 3 & 0.011469 & -57.34365 & 0.00002 & -0.10000 & 0.012112 & -60.55874 & 0.00002 & -0.10000 \\
\hline 4 & 0.009671 & -48.35539 & 0.00002 & -0.10000 & 0.010213 & -51.06654 & 0.00002 & -0.10000 \\
\hline 5 & 0.005918 & -29.59109 & 0.00002 & -0.10000 & 0.006250 & -31.25017 & 0.00002 & -0.10000 \\
\hline 6 & 0.001472 & -7.35903 & 0.00002 & -0.10000 & 0.001554 & -7.77163 & 0.00002 & -0.10000 \\
\hline 7 & 0.000496 & -2.48039 & 0.00002 & -0.10000 & 0.000524 & -2.61946 & 0.00002 & -0.10000 \\
\hline
\end{tabular}
reflectance (Mult ${ }_{\text {ref }}$ and Add $_{\text {ref }}$ ) of each pixel of the studied area 
constant, since they remained virtually unchanged along the five evaluated days. This result suggests that the obtained mean values, which are shown in Table 5, must be applied.

Surface albedo is one of the most important components of the surface radiation balance, which explains the great attention paid to its monitoring, especially in studies on changes in land use (Arraes et al., 2012; Oliveira et al., 2012). The albedo maps obtained with OLI images for the days of June $24(\mathrm{OD}=175)$, September $12(\mathrm{OD}=255)$ and October $14(\mathrm{OD}$ $=287)$ in the year of 2013 are represented in Figure 2. Areas with albedo lower than $9 \%$ comprehend the water bodies (São Gonçalo dam and small lakes, riverbeds and streams). Urban areas, in general, showed albedo higher than $25 \%$, which was also observed in areas of soil with great exposure. Irrigated plots in the SGID showed albedo from 16 to $18 \%$; however, in newly planted orchards (low vegetation index), the higher soil exposure caused an increase in albedo. For the images of $\mathrm{OD}=223$ and $\mathrm{OD}=303$, in the pixels corresponding to the clouds, the albedo was generally higher than $80 \%$ and, in areas shaded by the clouds, the values were lower than those of water, which is due to the method of calculation of the incident solar radiation in each pixel. The incident solar radiation was considered as constant; however, in the shades, it is significantly lower than in the other pixels, since under those conditions only solar radiation falls on the area. Thus, it is recommended the use of the most precise estimation of solar radiation in these pixels. Given the great heterogeneity of the area, the differentiation between irrigated crops and Caatinga, or soil with great exposure, is not very clear, particularly in the image of June, with storage of moisture in the soil, for being close to the rainy season.

Four targets were selected to verify albedo values in the three days without clouds, which are shown in Table 6. The location of each one of the selected targets is shown in Figure 2. According to Table 6, water albedo is between 3 and $8 \%$, while in the pixel of the urban area it remained between 28.3 and $31.2 \%$. On average, a values were equal to $5.3,18.2,16.6$ and $30.1 \%$ in the areas of the São Gonçalo dam, coconut orchard, central pivot with coconut trees and the urban area of Souza, respectively. These results agree with those of Silva et al. (2011), who obtained albedo higher than $80 \%$ for soils without vegetal cover and between 15 and $20 \%$ for irrigated crops. In general, a values corresponding to agricultural areas showed variation

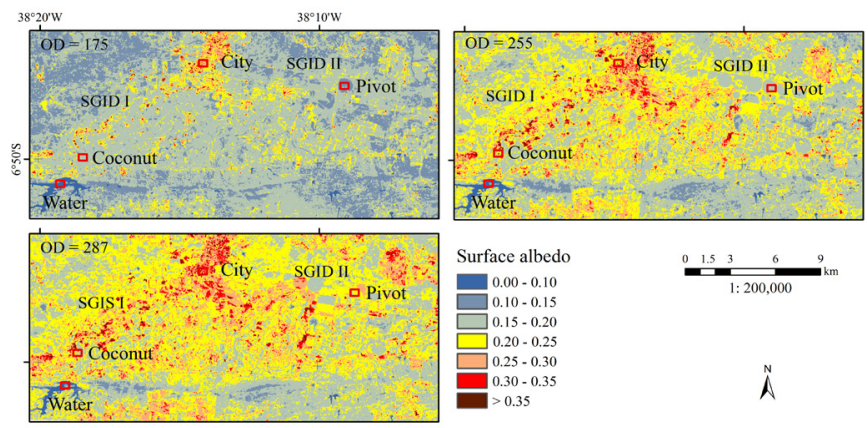

Figure 2. Thematic maps of surface albedo from Landsat 8 products in the São Gonçalo Irrigation District (SGID), referring to the ordinal dates (OD) 175, 255 and 287 in 2013
Table 6. Albedo of four targets for three selected ordinal dates (OD)

\begin{tabular}{ccccc}
\hline \multirow{2}{*}{ DD } & \multicolumn{4}{c}{ Target types } \\
\cline { 2 - 5 } 175 & Water & Coconut & Pivot & City \\
255 & 0.030 & 0.182 & 0.133 & 0.283 \\
287 & 0.050 & 0.178 & 0.169 & 0.308 \\
Mean Albedo & 0.080 & 0.187 & 0.196 & 0.312 \\
\hline
\end{tabular}

of $15-20 \%$ in all the studied targets. Areas with fruit crops, in Petrolina (Silva et al., 2005a), showed virtually constant a values, around $15 \%$. These values are consistent with the albedo estimated for fields under high vegetation cover, derived from the sensors TM - Landsat 5 and ETM+ - Landsat 7.

Between TM and OLI images, there was a systematic difference between albedo values; those obtained with OLI were higher than those generated with TM - Landsat 5. There are at least two explanations for this difference: one is related to the fact that OLI images (16 bits) have radiometric resolution substantially higher compared with TM (bits), and the other related to the environmental, since in 2012 and 2013 the rains were much lower than climatological normals, which characterize these years as years of drought with great coverage and intensity. This also affected irrigated areas, because irrigators had to ration water due to the decrease in the water volume of the São Gonçalo dam.

\section{Conclusions}

1. The solar constant values, specific of each one of the OLI-Landsat 8 bands, used in the albedo calculation, showed great differentiation between the studied days.

2. The weights used in the planetary albedo calculation (without atmospheric correction) can be represented by the obtained mean values, because they did not vary much.

3. The albedo of irrigated areas was more clearly different from native vegetation areas in months that are further away from the rainy season.

4. Albedo images show great degree of detail for the different types of land use and occupation, due to their high radiometric resolution.

\section{ACKNOWLedgments}

To the National Council for Scientific and Technological Development (CNPq), for the research productivity grant and PhD scholarships to some of the authors, and to the Research Support Foundation of Pernambuco (FACEPE) for the support to the project, which resulted in the present publication. The authors extend their thanks to the Journal's reviewers for their analysis, criticism, corrections and suggestions.

\section{Literature Cited}

Allen, R. G.; Tasumi, M.; Trezza, R. Satellite-based energy balance for mapping evapotranspiration with internalized calibration (METRIC) - Model. Journal of Irrigation and Drainage Engineering, v.133, p.380-394, 2007. http://dx.doi.org/10.1061/ (ASCE)0733-9437(2007)133:4(380) 
Allen, R. G.; Trezza, R.; Tasumi, M. Surface energy balance algorithms for land. Advance training and user's manual, version 1.0. Kimberly: The Idaho Department of Water Resources, 2002. 98p.

Arraes, F. D. D.; Andrade, E. M. de; Silva, B. B. da. Dinâmica do balanço de energia sobre o açude de Orós e suas adjacências. Revista Caatinga, v.25, p.119-127, 2012.

Bastiaanssen, W. G. M.; Menenti, M.; Feddes, R. A.; Holslag, A. A. M. A. Remote sensing surface energy balance algorithm for land (SEBAL) - Formulation. Journal of Hydrology, v.212-213, p.198212, 1998. http://dx.doi.org/10.1016/S0022-1694(98)00253-4

Bezerra, J. M.; Moura, G. B. de A.; Silva, B. B. da; Lopes, P. M. O.; Silva, E. F. de F. e. Parâmetros biofísicos obtidos por sensoriamento remoto em região semiárida do estado do Rio Grande do Norte, Brasil. Revista Brasileira de Engenharia Agrícola e Ambiental, v.18, p.123-130, 2014. http://dx.doi.org/10.1590/S141543662014000100010

Chander, G.; Markhan, B. Revised Landsat 5 - TM radiometric calibration procedures and post calibration dynamic ranges. IEEE Transactions on Geosciences and Remote Sensing, v.41, p.2674-2677, 2003. http://dx.doi.org/10.1109/TGRS.2003.818464

Chander, G.; Markham, B. L.; Helder, D. L. Summary of current radiometric calibration coefficients for Landsat MSS, TM, ETM+, and EO-1 ALI sensors. Remote Sensing of Environment, v.113, p.893-903, 2009. http://dx.doi.org/10.1016/j.rse.2009.01.007

Giongo, P. R.; Moura, G. B. A.; Silva, B. B. da; Rocha, H. R. da; Medeiros, S. R. R. de; Nazareno, A. C. Albedo à superfície a partir de imagens Landsat 5 em áreas de cana-de-açúcar e cerrado. Revista Brasileira de Engenharia Agrícola e Ambiental, v.14, p.279-287, 2010. http:// dx.doi.org/10.1590/S1415-43662010000300007

Gusmão, A. C. V. L.; Silva, B. B. da; Montenegro, S. M. G. L.; Galvíncio, J. D. Determinação do saldo radiativo na Ilha do Bananal, TO, com imagens orbitais. Revista Brasileira de Engenharia Agrícola e Ambiental, v.16, p.1107-1114, 2012. http://dx.doi.org/10.1590/ S1415-43662012001000011

Hucek, R.; Jacobowitz, H. Impact of scene dependency on AVHRR albedo models. Journal of Atmospheric and Oceanic Technology, v.12, p.697-711, 1995. http://dx.doi.org/10.1175/1520-0426(1995) 012\%3C0697:IOSDOA\%3E2.0.CO;2

Krayenhoff, E. S.; Voogt, J. A. Impacts of urban albedo increase on local air temperature at daily-annual time scales: model results and synthesis of previous work. Journal of Applied Meteorology and Climatology, v.49, p.1634-1648, 2010. http://dx.doi. org/10.1175/2010JAMC2356.1

Liang, S. Narrowband to broadband conversions of land surface albedo I Algorithms. Remote Sensing of Environment, v.76, p.213238, 2000. http://dx.doi.org/10.1016/S0034-4257(00)00205-4

Loew, A.; Govaerts, Y. Towards multidecadal consistency meteosat surfasse albedo. Remote Sensing, v.2, p.957-967, 2010. http:// dx.doi.org/10.3390/rs2040957

Lopes, P. M. O.; Valeriano, D. de M.; Silva, B. B. da; Moura, G. B. A.; Silva, A. O. Simulação do saldo de radiação na Serra da Mantiqueira. Revista Brasileira de Engenharia Agrícola e Ambiental, v.17, p.780-789, 2013. http://dx.doi.org/10.1590/ S1415-43662013000700013
Machado, C. C. C.; Silva, B. B. da; Albuquerque, M. B.; Galvíncio, J. D. Estimativa do Balanço de energia utilizando imagens TM - Landsat 5 e o algoritmo SEBAL no litoral sul de Pernambuco. Revista Brasileira de Meteorologia, v.29, p.55-67, 2014. http:// dx.doi.org/10.1590/S0102-77862014000100006

Mattar, C.; Franch, B.; Sobrino, J. A.; Corbari, C.; Jiménez-Muñoz, J. C.; Olivera-Guerra, L.; Skokovic, D.; Sória, G.; Oltra-Carriò, R.; Julien,Y.; Mancini, M. Impacts of the broadband albedo on actual evapotranspiration estimated by S-SEBI model over an agricultural area. Remote Sensing of Environment, v.147, p.23-42, 2014. http://dx.doi.org/10.1016/j.rse.2014.02.011

Mueller, R.; Trentmann, J.; Trager-Chatterjee, C.; Posselt, R.; Reto Stockli, R. The role of the effective cloud albedo for climate monitoring and analysis. Remote Sensing, v., p.2305-2320, 2011.

Oliveira, L. M. M.; Montenegro, S. M. G. L.; Antonino, A. C. D.; Silva, B. B. da; Machado, C. C. C.; Galvíncio, J. D. Análise quantitativa de parâmetros biofísicos de bacia hidrográfica, obtidos por sensoriamento remoto. Pesquisa Agropecuária Brasileira, v.47, p.1209-1217, 2012. http://dx.doi.org/10.1590/ S0100-204X2012000900005

Rodrigues, J. O.; Andrade, E. M. de; Teixeira, A. S.; Silva, B. B da. Sazonalidade de variáveis biofísicas em região semiárida pelo emprego do sensoriamento remoto. Engenharia Agrícola, v.29, p.452465, 2009. http://dx.doi.org/10.1590/S0100-69162009000300012

Silva, B. B. da; Bezerra, M. V. C. Determinação dos fluxos de calor sensível e latente na superfície utilizando imagens TM - Landsat 5. Revista Brasileira de Agrometeorologia, v.14, p.174-186, 2006. Silva, B. B. da; Braga, A. C.; Braga, C. C. Balanço de radiação no perímetro irrigado São Gonçalo - PB mediante imagens orbitais. Revista Caatinga, v.24, p.145-152, 2011.

Silva, B. B. da; Lopes, G. M.; Azevedo, P. V. de. Determinação do albedo de áreas irrigadas com base em imagens Landsat 5-TM. Revista Brasileira de Agrometeorologia, v.13, p.201-211, 2005a.

Silva, B. B. da; Lopes, G. M.; Azevedo, P. V. de. Balanço de radiação em áreas irrigadas utilizando imagens Landsat 5 - TM. Revista Brasileira de Meteorologia, v.20, 243-252, 2005b.

Souza, J. D. de; Silva, B. B. da; Ceballos, J. C. Surface albedo obtained with MODIS images in cases of low and high aerosol loading in the atmosphere. Revista Brasileira de Geofísica, v.32, p.5-20, 2014.

Tasumi, M.; Allen, R. G.; Trezza, R. At-surface reflectance and albedo from satellite for operational calculation of land surface balance. Journal of Hydrologic Enginnering, v.13, p.51-63, 2008. http:// dx.doi.org/10.1061/(ASCE)1084-0699(2008)13:2(51)

Thornthwaite, C. W.; Matther, J. R. The water balance. Centerton: Drexel Institute of Technology - Laboratory of Climatology. 1944. 104p.

Wang, S; Davidson, A. Impact of climate variations on surface albedo of a temperate grassland. Agricultural and Forest Meteorology, v.142, p.133-142, 2007.

Wydick, J.; Davies, P.; Gruber, A. Estimation of broadband planetary albedo from operational narrowband satellite measurements. Washington: National Oceanic and Atmospheric Administration, 1987. 32p, NOAA Technical Report, NESDIS 27.

Zhong, Q.; Li, Y. H. Satellite observation of surface albedo over the Qinghai-Xizang plateau region. Advances in Atmospheric Science, v.5, p.57-65, 1988. http://dx.doi.org/10.1007/BF02657346 